\title{
ARTICLE
}

\section{Regulatory Chill in a Warming World: The Threat to Climate Policy Posed by Investor-State Dispute Settlement}

\author{
Kyla Tienhaara*
}

First published online 22 December 2017

\begin{abstract}
The system of investor-state dispute settlement (ISDS) found in over 3,000 bilateral investment treaties and numerous regional trade agreements has been criticized for interfering with the rights of sovereign states to regulate investment in the public interest, for example, to protect the environment and public health. This article argues that while much of the public debate around ISDS has focused on a small number of cases that have arisen over the regulation of tobacco packaging, there is a far greater threat posed by the potential use of ISDS by the fossil fuel industry to stall action on climate change. It is hypothesized that fossil fuel corporations will emulate a tactic employed by the tobacco industry - that of using ISDS to induce cross-border regulatory chill: the delay in policy uptake in jurisdictions outside the jurisdiction in which the ISDS claim is brought. Importantly, fossil fuel corporations do not have to win any ISDS cases for this strategy to be effective; they only have to be willing to launch them. The article concludes with three options to reform trade and investment agreements to better align them with climate change mitigation efforts: (i) exclude ISDS provisions; (ii) prohibit fossil fuel industries from accessing ISDS; or (iii) carve out all government measures taken in pursuit of international obligations (for example, under the Paris Agreement on climate change) from challenge under ISDS.
\end{abstract}

Keywords: Investment, Fossil fuels, Climate change, Arbitration, Investor-state dispute settlement (ISDS)

\section{INTRODUCTION}

Not all investments are created equal. In some instances foreign direct investment (FDI) leads to substantial job creation, positive spillover effects, and the introduction of novel and useful technologies. In other cases, FDI crowds out local investment, creates pollution and contributes little to nothing to the economy. This has always

* School of Regulation and Global Governance, Australian National University, Canberra (Australia). Email: kyla.tienhaara@anu.edu.au.

I would like to acknowledge the feedback on earlier drafts of this article received from participants at the Global Governance and the Trans-Pacific Partnership (TPP) Symposium at the University at Buffalo, NY (United States (US)) in Nov. 2016, as well as from two anonymous reviewers for TEL. 
been the case, but in a climate-constrained world it is ever more apparent that FDI is not an unmitigated good.

In 2015, 187 governments took a step closer to reaching the conclusion that investment in fossil fuels must end by signing the Paris Agreement ${ }^{1}$ under the United Nations Framework Convention on Climate Change (UNFCCC). ${ }^{2}$ In this agreement, countries committed to keeping average global temperature change below 2 degrees Celsius $\left({ }^{\circ} \mathrm{C}\right)$ of warming above pre-industrial levels. McGlade and Ekins have demonstrated that in order to have a reasonable chance of meeting this commitment globally, a third of oil reserves, half of gas reserves and over $80 \%$ of current coal reserves should remain unused from 2010 to $2050 .^{3}$ This means that a substantial proportion of known fossil fuel deposits would have to be left in the ground and further exploration activities could not be undertaken. While it is true that most governments have yet to accept this reality, barring an unlikely and dramatic technological breakthrough (for example, the development of a viable and scalable method of carbon capture and storage), they will have to begin curtailing fossil fuel investments in the very near future.

In this context, it is important to recognize that over 3,000 bilateral investment treaties (BITs) include provisions to provide legal protection for all forms of foreign investment, including investment in sectors that must eventually be rendered obsolete to prevent warming beyond the $2^{\circ} \mathrm{C}$ limit set by the Paris Agreement. Additionally, regional trade agreements such as the North American Free Trade Agreement (NAFTA), ${ }^{4}$ as well as a new wave of agreements (not yet in force) - namely the TransPacific Partnership (TPP), ${ }^{5}$ the Transatlantic Trade and Investment Partnership (TTIP), ${ }^{6}$ the Regional Comprehensive Economic Partnership (RCEP), ${ }^{7}$ and the Comprehensive Economic and Trade Agreement (CETA $)^{8}-$ will have chapters on investment protection. Specifically, all of these agreements (except the CETA) will provide corporations with access to a process known as investor-state dispute settlement (ISDS). ${ }^{9}$ This process allows foreign investors to bypass local courts and bring claims for monetary compensation to an international tribunal. Investment tribunals are composed of three private parties (arbitrators): one chosen by the state

1 Paris (France), 13 Dec. 2015, in force 4 Nov. 2016, available at: http://unfccc.int/paris_agreement/ items/9485.php.

2 New York, NY (US), 9 May 1992, in force 21 Mar. 1994, available at: http://unfccc.int.

3 C. McGlade \& P. Ekins, 'The Geographical Distribution of Fossil Fuels Unused when Limiting Global Warming to $2^{\circ} \mathrm{C}^{\prime}$ (2015) 517(7533) Nature, pp. 186-90, at 187.

4 Ottawa, ON (Canada), Mexico City (Mexico), Washington, DC (US), 17 Dec. 1992, in force 1 Jan. 1994, available at: http://www.international.gc.ca/trade-commerce/assets/pdf.

5 Wellington (New Zealand), 4 Feb. 2016, not in force, available at: https:/www.mfat.govt.nz/en/aboutus/who-we-are/treaties/trans-pacific-partnership-agreement-tpp/text-of-the-trans-pacific-partnership.

6 Negotiations pending; see at: http://ec.europa.eu/trade/policy/in-focus/ttip.

7 Negotiations pending; see at: http://dfat.gov.au/trade/agreements/rcep/pages/regional-comprehensiveeconomic-partnership.aspx.

8 Comprehensive Economic and Trade Agreement between Canada, of the one part, and the European Union and its Member States, of the other part (CETA), Brussels (Belgium), 14 Sept. 2016, not in force, available at: http://data.consilium.europa.eu/doc/document/ST-10973-2016-INIT/en/pdf.

9 The CETA contains a modified version of ISDS which has been referred to as an investment court system: European Commission, 'A Future Multilateral Investment Court - Factsheet', 13 Dec. 2016, available at: http://europa.eu/rapid/press-release_MEMO-16-4350_en.htm. 
involved in the dispute; one chosen by the investor; and a third that is mutually agreed upon or, failing that, appointed by an arbitral body such as the International Centre for the Settlement of Investment Disputes (ICSID).

In 2015, the year in which the Paris Agreement and the TPP were signed (although not yet in force), a record number of 70 ISDS cases were launched. The United Nations Conference on Trade and Development (UNCTAD) has documented 767 known disputes in total (a lack of transparency in the system means that this could be a substantial underestimation). ${ }^{10}$ The ISDS cases brought by tobacco giant Philip Morris against Uruguay and Australia over the introduction of strict cigarette packaging laws are perhaps the most notorious. ${ }^{11}$ However, disputes related to tobacco or health more broadly are quite rare. Of all the disputes registered with ICSID up to $2015,26 \%$ concerned oil, gas and mining (more than any other sector) and another $15 \%$ concerned electric power and other energy resources. ${ }^{12}$ Thus, $41 \%$ of all ICSID cases relate to the energy sector or extractive industries.

Recently, there has been a surge of ISDS cases launched by renewable energy companies (primarily against Spain). ${ }^{13}$ Nonetheless, long-established industry players bring the majority of claims. The ISDS system works best for incumbents because it was designed to ensure stability in the investment environment. States are expected to maintain the conditions that were conducive to attracting incumbent investors in the first place, and may be punished if they change their policy position. Such a framework provides cause for concern given the significant policy developments required to transition to a low-carbon economy. At present, there are no known cases where an investor has taken the step of formally launching ISDS over the introduction of a carbon tax, emissions trading scheme or renewable energy incentive scheme. The latter have been challenged only when modified with retroactive effect. ${ }^{14}$ However, claims have certainly been contemplated, including against the Australian government's proposed carbon pollution reduction scheme in $2009 .^{15}$

ISDS cases have arisen in response to:

- a moratorium on oil and gas operations within 12 nautical miles of the Italian coastline; ${ }^{16}$

10 UNCTAD, 'Investment Dispute Settlement Navigator', updated 1 Jan. 2017, available at: http://investmentpolicyhub.unctad.org/ISDS.

11 Philip Morris Brands Sàrl, Philip Morris Products S.A. and Abal Hermanos S.A. v. Oriental Republic of Uruguay, ICSID Case No. ARB/10/7, available at: https://www.italaw.com/cases/460; Philip Morris Asia Ltd v. The Commonwealth of Australia, UNCITRAL, PCA Case No. 2012-12, available at: https://www.italaw.com/cases/851.

12 ICSID 'The ICSID Caseload - Statistics' (2015), available at: https://icsid.worldbank.org/en/ Documents/resources/ICSID\%20Web\%20Stats\%202015-2\%20(English).pdf.

13 See further K. Tienhaara \& C. Downie, 'Risky Business: The Energy Charter Treaty, Renewable Energy and Investor-State Disputes', Global Governance (forthcoming).

14 Ibid.

15 K. Miles, The Origins of International Investment Law: Empire, Environment and the Safeguarding of Capital (Cambridge University Press, 2013), p. 202.

16 'Italy's Ban on Oil and Gas Development Near Its Coastline Leads to Investment Treaty Arbitration Claim', IAReporter, 23 Mar. 2017, available at: https://www-iareporter-com.virtual.anu.edu.au/articles/italys-banon-oil-and-gas-development-near-its-coastline-leads-to-investment-treaty-arbitration-claim. 
- restrictions placed on a coal-fired power station by the German city of Hamburg; ${ }^{17}$

- a ban by the Canadian Province of Quebec on hydraulic fracturing ('fracking', a process with potentially significant climate impacts through methane releases as well as implications for groundwater); ${ }^{18}$ and

- the United States (US) Obama administration's rejection of a proposal by TransCanada Corporation to build the Keystone XL pipeline to transport oil produced from Alberta's tar sands to various refineries in the US. ${ }^{19}$

The German case was settled and, at the time of writing, the case in Quebec had not concluded, whereas the Italian case was only in the very early stages. TransCanada withdrew its claim against the US following President Trump's executive order allowing construction of the Keystone XL pipeline to move ahead. ${ }^{20}$

Obama's rejection of Keystone XL was probably influenced by his desire to demonstrate leadership on climate change in the run-up to the Paris Climate Conference. $^{21}$ While it is unlikely that the existence of the ISDS case factored into Trump's decision to allow the pipeline to proceed, it is worth noting that when the case was launched, a number of legal experts suggested that TransCanada (seeking US\$15 billion in damages) had a good chance of winning. ${ }^{22}$ In a different jurisdictional context, a case like this would have had the potential to create regulatory chill, which is the main focus of this article.

The regulatory chill hypothesis suggests that governments will fail to regulate in the public interest in a timely and effective manner because of concerns about ISDS. ${ }^{23}$ This article outlines three distinct varieties of regulatory chill: internalization chill, threat chill, and cross-border chill. It also details why regulatory chill is of particular concern in the climate change policy space, drawing parallels between the fossil fuel and tobacco industries. Finally, the article addresses how some governments are dealing with regulatory chill: by introducing 'safeguards' and, in the case of the TPP, specifically carving out tobacco policies from ISDS provisions. Trump's withdrawal from the TPP has rendered it defunct (although there is still the possibility that a

17 N. Bernasconi, 'Background Paper on Vattenfall v. Germany Arbitration', International Institute for Sustainable Development, July 2009, available at: https://www.iisd.org/sites/default/files/publications/ background_vattenfall_vs_germany.pdf.

18 Lone Pine Inc. v. Government of Canada, ICSID Case No. UNCT/15/2, available at: http://www.international. gc.ca/trade-agreements-accords-commerciaux/topics-domaines/disp-diff/lone.aspx?lang=eng.

19 Trans Canada Corporation and TransCanada Pipelines Ltd v. United States of America, ICSID Case No. ARV/16/21.

20 According to the ICSID website, the case was discontinued on 24 Mar. 2017, available at: https://icsid.worldbank.org/en/Pages/cases/casedetail.aspx?CaseNo=ARB/16/21.

21 C. Mooney, 'How Obama's Keystone XL Rejection Adds Momentum to the Paris Climate Talks', The Washington Post, 6 Nov. 2015, available at: https:/www.washingtonpost.com/news/energyenvironment/wp/2015/11/06/how-obamas-keystone-xl-rejection-gives-him-momentum-for-the-paris-climatetalks/?utm_term=.d044d4bc43b2.

22 L. Krugel, 'TransCanada NAFTA Challenge Could Break U.S. Winning Streak, Experts Say', CTV News, 7 Jan. 2016, available at: http://www.ctvnews.ca/business/transcanada-nafta-challenge-couldbreak-u-s-winning-streak-experts-say-1.2728344.

23 K. Tienhaara, 'Regulatory Chill and the Threat of Arbitration: A View from Political Science', in C. Brown \& K. Miles (eds), Evolution in Investment Treaty Law and Arbitration (Cambridge University Press, 2011), pp. 606-28, at 615. 
modified 'TPP minus one' version will be negotiated ${ }^{24}$ ), but its text continues to have an influence on other agreements, such as the RCEP. This article argues that, in these agreements, governments should not limit themselves to a narrow tobacco carve-out and that Big Oil actually poses a greater threat to public policy than Big Tobacco. One option would be for negotiators to broaden the scope of the carve-out to cover all government measures taken in pursuit of international obligations, including those found in climate change treaties.

\section{VARIETIES OF REGULATORY CHILL}

There is a common misconception that governments can be forced by ISDS tribunals to roll back regulations that have been put in place; this is not the case. ${ }^{25}$ As such, ISDS has no direct impact on health and environmental regulation. However, there is significant potential for indirect impacts to occur as a result of the effect ISDS has 'on the way in which host states exercise their regulatory powers'. ${ }^{26}$ ISDS is expected to have an effect on states because of the substantial financial risk involved (governments have been found liable for hundreds of millions and, in some cases, even billions of dollars) as well as the difficulty in predicting outcomes. ${ }^{27}$ The debate on this topic in the literature and in policy circles has generally been framed around the phenomenon known as regulatory chill. ${ }^{28}$ As indicated earlier, the regulatory chill hypothesis suggests that in some instances (not all, or there would be no ISDS cases) governments will fail to enact or enforce bona fide regulatory measures (or modify measures to such an extent that their original intent is undermined or their effectiveness is severely diminished) as a result of concerns about ISDS. ${ }^{29}$

Two distinct types of regulatory chill have been discussed in the literature. This article proposes a third variant.

\subsection{Internalization Chill}

Internalization chill is a process whereby regulatory progress is dampened across all areas that affect foreign investors because government officials are concerned about the risk of an investor-state dispute arising. ${ }^{30}$ Policy makers take into account potential disputes with foreign investors before they even begin to draft a policy, thereby prioritizing the avoidance of such disputes over the development of efficient regulation

24 Negotiators from 11 countries met in Sydney (Australia) in Aug. 2017 in an attempt to revive the agreement: 'TPP Countries Consider Amendments to Stalled Trade Deal: Sources', Reuters, 29 Aug. 2017, available at: https:/www.reuters.com/article/us-trade-tpp-australia/tpp-countriesconsider-amendments-to-stalled-trade-deal-sources-idUSKCN1B90KP.

25 E.g., Friends of the Earth Europe, 'Unfair Privileges for Investors', available at: http://www.foeeurope.org/isds.

26 J. Bonnitcha, Substantive Protection under Investment Treaties: A Legal and Economic Analysis (Cambridge University Press, 2014), p. 114.

27 Tienhaara, n. 23 above, p. 615; UNCTAD, 'Recent Developments in Investor-State Dispute Settlement', IIA Issues Note, No. 1, Apr. 2014, available at: http://unctad.org/en/PublicationsLibrary/ webdiaepcb2014d3_en.pdf.

28 Bonnitcha, n. 26 above; Miles, n. 15 above; Tienhaara, n. 23 above.

29 Tienhaara, n. 23 above, p. 610.

30 Bonnitcha, n. 26 above. 
in the public interest. Internalization chill is extremely difficult to measure. It requires 'counterfactual evidence about the regulations that would have existed in the absence of the purported chilling', in addition to untangling the regulatory decision-making process and identifying the key factors that resulted in the failure to adopt a measure. ${ }^{31}$

Evidence of internalization chill in the literature is limited and mixed. Côté conducted interviews with regulators in health, safety and environment agencies in the Canadian federal government and concluded that overall awareness of ISDS tended to be low across the board and, as such, that the potential for internalization chill was low. ${ }^{32}$ However, she did find that awareness was greater among the highest-ranking officials and in those agencies that had been directly involved in disputes. Van Harten and Scott also conducted interviews with regulators in Canada, but at the provincial level (a significant percentage of ISDS cases in Canada have arisen over subnational government measures). ${ }^{33}$ They found that government ministries have changed their decision making to account for concerns about ISDS and that government legal advisers play a key role in assessing ISDS risks.

The findings of Van Harten and Scott suggest that, while the everyday regulator may have no awareness of ISDS (as suggested by Côté), practices developed within government to ensure that policies are vetted by lawyers with expertise in investment law prior to adoption could lead to regulatory chill. ${ }^{34}$ This is also supported by the comments of one of the world's leading arbitration lawyers, Toby Landau, who stated on an Australian radio programme in 2014:

Without a doubt. Regulatory chill, so-called, in my opinion definitely exists, and there's palpable evidence of it. There are those who deny it, but I can say that, in my role as counsel, on a number of occasions now, I've actually been instructed by governments to advise on possible adverse implications or consequences of a particular policy in terms of investor-state cases. ${ }^{35}$

A number of countries now have mechanisms in place to screen health and environmental policies for potential trade and investment impacts prior to their implementation. ${ }^{36}$ For example, Regulatory Impact Analysis Statements in Canada necessitate the consideration of trade and investment implications of any new regulation. ${ }^{37}$ Several governments in the developing world have also recently embarked on comprehensive ISDS implementation policies, some of which include

31 Ibid., p. 115.

32 C. Côté, 'A Chilling Effect? The Impact of International Investment Agreements on National Regulatory Autonomy in the Areas of Health, Safety and the Environment' (PhD thesis, London School of Economics, Feb. 2014).

33 G. Van Harten \& D.N. Scott, 'Investment Treaties and the Internal Vetting of Regulatory Proposals: A Case Study from Canada' (2016) 7(1) Journal of International Dispute Settlement, pp. 1-25.

34 Ibid.

35 Quoted in J. Hill, 'ISDS: The Devil in the Trade Deal', Background Briefing, ABC Radio National Australia, 26 July 2015, available at: http://www.abc.net.au/radionational/programs/back groundbriefing/isds-the-devil-in-the-trade-deal/6634538.

36 UNCTAD, Investor-State Disputes: Prevention and Alternatives to Arbitration, UNCTAD Series on International Investment Policies for Development (United Nations, 2010), available at: http://unctad.org/en/docs/diaeia200911_en.pdf.

37 Bonnitcha, n. 26 above; Côté, n. 32 above. 
the development of 'dispute prevention' mechanisms. ${ }^{38}$ The UNCTAD Secretariat has assisted the governments of Peru, Guatemala, Panama and the Dominican Republic in setting up such policies and mechanisms. The focus of UNCTAD's work is to help developing countries in preventing costly disputes from arising. However, the organization does not appear to have considered the impact that these types of arrangement will have on regulatory authority. Will they increase the likelihood of settlements in which regulations are changed or not implemented and thus, in effect, institutionalize regulatory chill? Alternatively, will they conversely increase regulatory confidence in the ability of a measure to survive a challenge and thereby reduce any chilling effect? Although these types of arrangement have been mentioned in discussions of regulatory chill, ${ }^{39}$ they have not been adequately assessed from a regulatory perspective.

\subsection{Threat Chill}

Threat chill is the most familiar form of regulatory chill. It concerns the chilling of specific regulatory measures that have been proposed by governments following an investor's threat to arbitrate. A regulatory lack of awareness about ISDS is irrelevant to this type of chill. In fact, a lack of knowledge about the specifics of investment law makes the threat of arbitration all the more potent, because regulators will be less likely to recognize when an investor is bluffing. ${ }^{40}$

The fact that investors brandish ISDS as a threat is indisputable; law firms actively advertise ISDS as a useful tool 'to assist lobbying efforts to prevent wrongful regulatory change'. ${ }^{41}$ The empirical question is, therefore, whether governments take these threats seriously and change their behaviour as a result.

Defenders of ISDS argue that if measures are bona fide public policies, governments do not have to worry about threats of arbitration. ${ }^{42}$ However, such assertions are overly simplistic. First of all, in practice regulation is a messy business and governments frequently have multiple motivations for adopting regulatory measures. The extant case law demonstrates that the various actors involved in ISDS cases have held widely diverging opinions on where the line between bona fide and illegitimate measures should be drawn. Furthermore, regulators are subject to bounded rationality: they experience time and resource constraints and face serious limitations on their ability to predict the outcomes of legal cases. ${ }^{43}$ This is particularly

38 UNCTAD, n. 36 above.

39 See, e.g., Bonnitcha, n. 26 above; Van Harten \& Scott, n. 33 above.

40 Tienhaara, n. 23 above.

41 M. Coleman et al., 'Foreign Investors' Options to Deal with Regulatory Changes in the Renewable Energy Sector', Steptoe \& Johnson LLP, 23 Sept. 2014, available at: http://www.steptoe.com/ publications-9867.html.

42 J. Coe \& N. Rubins, 'Regulatory Expropriation and the Tecmed Case: Context and Contributions', in T. Weiler (ed.), International Investment Law and Arbitration: Leading Cases from the ICSID, NAFTA, Bilateral Treaties and Customary International Law (Cameron May, 2005), pp. 597-667, at 599; S. Schill, 'Do Investment Treaties Chill Unilateral State Regulation to Mitigate Climate Change?' (2007) 24(5) Journal of International Arbitration, pp. 469-77, at 470.

43 Tienhaara, n. 23 above; Poulsen argues that bounded rationality also explains why developing countries agree to sign investment treaties in the first place: L. Poulsen, Bounded Rationality and Economic Diplomacy: The Politics of Investment (Cambridge University Press, 2015). 
true in ISDS because the ambiguous nature of the provisions found in investment treaties leaves significant scope for arbitrators to interpret the law (for example, the requirement to provide fair and equitable treatment), and because awards rendered in investment arbitration are binding only on the parties involved in the dispute (there is no system of precedent). In this environment of uncertainty, governments may have a distorted perception of their chances of success in arbitration, and may also be reluctant to risk a negative outcome because the stakes involved in ISDS are very high. Even if a government wins a case, it may be burdened with a significant legal bill. ${ }^{44}$ Regulators in developing countries are likely to be especially cautious about inciting an ISDS case given the limited capacity of their governments to cover this level of costs.

As Miles notes: 'In operation, [regulatory chill] is generally a subtle creature and is difficult to detect. And yet, it has the potential to frustrate initiatives designed to implement national and global environmental objectives'. ${ }^{45}$ One example of threat chill that has been detailed in the literature, ${ }^{46}$ and more recently in the media, ${ }^{47}$ is Indonesia's decision to allow open-pit mining in protected forests following a threat of arbitration. In-depth case studies of this nature are often dismissed as anecdotal. To some extent, this may reflect a bias in the trade and investment field against qualitative social science methodologies. However, it is true that results have sometimes been inconclusive because researchers are unable to find a smoking gun. Government officials are wary of disclosing information about ISDS threats for a variety of reasons and would be understandably reluctant in many cases to admit that they abandoned a bona fide measure that was in the public interest out of fear of ISDS, especially if they have signed or continue to sign treaties providing access to arbitration.

Furthermore, an arbitration threat is likely to be just one in a suite of tools employed by an investor faced with a potentially negative regulatory change. Investors will also employ more traditional lobbying tactics and threats to exit the jurisdiction, ${ }^{48}$ with consequences in terms of job losses and lost government revenue. Distinguishing the relative importance of these various tactics in influencing a government is very difficult. Additionally, they may act to reinforce one another. In Australia, for example, the tobacco industry launched a multimillion dollar public relations campaign to oppose legislation mandating the plain packaging of cigarettes.

44 D. Gaukrodger \& K. Gordon, 'Investor-State Dispute Settlement: A Scoping Paper for the Investment Policy Community', Organization for Economic Cooperation and Development (OECD), Working Papers on International Investment, No. 2012/3, available at: http://www.oecd.org/daf/inv/investmentpolicy/WP-2012_3.pdf.

45 Miles, n. 15 above, p. 187.

46 S. Gross, 'Inordinate Chill: BITS, Non-NAFTA MITS, and Host-State Regulatory Freedom: An Indonesian Case Study' (2003) 24(3) Michigan Journal of International Law, pp. 893-960; K. Tienhaara, The Expropriation of Environmental Governance: Protecting Foreign Investors at the Expense of Public Policy (Cambridge University Press, 2009), pp. 217-27.

47 C. Hamby, 'The Billion Dollar Ultimatum', BuzzFeed News, 30 Aug. 2016, available at: https://www.buzzfeed. com/chrishamby/the-billion-dollar-ultimatum?utm_term=.jp5wJ8wv1L\#.otPBG2BkMD.

48 N. Jensen, Nation-States and the Multinational Corporation: A Political Economy of Foreign Direct Investment (Princeton University Press, 2006), p. 78; L. Mosely, Global Capital and National Governments (Cambridge University Press, 2003), p. 29. 
Included in some of the advertisements in this campaign was the claim that the legislation would waste taxpayers' money because it would mire the government in costly litigation, including ISDS. ${ }^{49}$ While this strategy ultimately proved unsuccessful for Big Tobacco, it points to the fact that the threat of ISDS can be used in multiple ways.

\subsection{Cross-Border Chill}

Recent experience with tobacco control measures suggests that there is a need to distinguish a third form of regulatory chill. Tobacco corporations have certainly directly threatened countries with legal action - for example, in Namibia, Togo and Uganda $^{50}$ - but a broader implicit threat has also been created by Philip Morris actually launching ISDS cases in Uruguay and Australia. ${ }^{51}$

Defenders of ISDS have continued to misunderstand how regulatory chill operates in this context and cite the recent victories of Uruguay and Australia as proof that a chilling effect does not exist. ${ }^{52}$ There are a number of flaws with this reasoning. In the case of Uruguay, the government has acknowledged that it would not have been able to defend itself in ISDS without the financial support of a foundation set up by Michael Bloomberg. ${ }^{53}$ The country's success in the case, therefore, does not disprove regulatory chill. Instead, it reinforces the notion that the high cost of ISDS can be sufficient to dissuade a government from defending a policy that would ultimately be determined to be compliant with international investment law. As for Australia, the case was decided on jurisdiction; consequently, it has no bearing on the regulatory chill debate.

More importantly, the real issue with these cases is not who won and who lost (most experts predicted that Philip Morris would lose), ${ }^{54}$ although it is concerning that there was a dissenting opinion in the Uruguay case. Rather, the issue is how tobacco corporations exploited the existence of these cases over the many years during which they dragged on and how governments have responded. Margaret Chan, Director General of the World Health Organization (WHO), has stated that

49 A. Mitchell \& D. Studdert, 'Plain Packaging of Tobacco Products in Australia: A Novel Regulation Faces Legal Challenge' (2012) 307(3) Journal of the American Medical Association, pp. 261-2.

50 A. Schram, R. Labonté \& A. Ruckert, 'Philip Morris v Australia: A Crushing Blow to Big Tobacco or a Deferral of Sentencing for Plain Packaging?', Healthy Policies Blog, 3 Feb. 2016, available at: http://www.healthypolicies.com/2016/02/philip-morris-v-australia-a-crushing-blow-to-big-tobacco-ora-deferral-of-sentencing-for-plain-packaging.

51 N. 11 above.

52 See, e.g., N. Lavrnos, 'After Philip Morris II: States Maintain Their Regulatory Powers to Control the Plain Packaging of Cigarettes', Practical Law Arbitration Blog, 15 Aug. 2016, available at: http://arbitrationblog.practicallaw.com/after-philip-morris-ii-states-maintain-their-regulatory-powersto-control-the-plain-packaging-of-cigarettes.

53 S. Tavernise, 'Tobacco Firms' Strategy Limits Poorer Nations' Smoking Laws', The New York Times, 13 Dec. 2013, available at: http://www.nytimes.com/2013/12/13/health/tobacco-industry-tactics-limitpoorer-nations-smoking-laws.html? pagewanted=all\&_r=3\&.

54 Mitchell \& Studdert, n. 49 above, p. 262; T. Voon \& A. Mitchell, 'Implications of International Investment Law for Plain Tobacco Packaging: Lessons from the Hong Kong-Australia BIT', in T. Voon, A. Mitchell \& J. Lieberman (eds), Public Health and Plain Packaging of Cigarettes: Legal Issues (Edward Elgar, 2012), pp. 137-72, at 172. 
the ISDS cases were 'deliberately designed to instill fear' in countries trying to reduce smoking. ${ }^{55}$ As Gruszczynski points out, the aggressive strategy taken by Big Tobacco against Australia, which is a relatively small market for cigarettes, can be explained by 'the precedential nature of the new law and a fear that the packaging requirements will be copied in other jurisdictions', and further notes that 'their approach sends a strong signal to other countries contemplating the introduction of plain packaging laws that any such initiative may be challenged'. ${ }^{56}$ Both Gruszczynski and Bonnitcha argue that New Zealand's decision to delay plain packaging until the dispute against Australia had been resolved is a clear-cut case of regulatory chill. ${ }^{57}$

Based on this example, this article proposes a third distinct variety of regulatory chill: cross-border chill. Investors pursue this type of chilling effect when a government adopts a policy that affects a form of investment common to many jurisdictions, is easily transferable, and is highly likely to be emulated by other governments. The most effective way to induce this type of chill is to actually launch an ISDS case in one or more jurisdictions (preferably the first jurisdiction that adopts a policy if an investment treaty is accessible). The aim from the investor's perspective in launching a case is not necessarily to prevent or delay the take-up of a policy in the jurisdiction in which the claim is brought - this jurisdiction might not even represent a particularly important market or investment location - but in all other jurisdictions in which the investor is active. It is significant to note that even if a delay in the adoption of a policy is the best that an investor can hope for (for example, if it has very little chance of actually winning the ISDS case), the lengthy duration of ISDS cases can mean that the investor reaps significant economic rewards from this strategy, which far outweigh the costs of the ISDS case itself.

Dow AgroSciences LLC v. Canada is another case in which cross-border chill, this time of the subnational rather than national variety, was the likely aim of the investor. ${ }^{58}$ In this case, Dow challenged Québec's 2003 Pesticides Management Code, ${ }^{59}$ which banned the use of the pesticide's active ingredient 2,4-D for cosmetic purposes (i.e. lawn care) in the province. Québec's regulators relied on the precautionary principle as justification for their ban of 2,4-D in the absence of conclusive scientific evidence of its environmental and health impacts. At the time, numerous other municipal and provincial governments were in the process of considering similar cosmetic pesticide bans. ${ }^{60}$ Dow sought CAD $\$ 2$ million plus costs. This paltry sum, which was lower than the average cost to participate in an ISDS case,

55 M. Chan, 'The Changed Face of the Tobacco Industry', Keynote Address at the $15^{\text {th }}$ World Conference on Tobacco and Health, Singapore, 20 Mar. 2012, available at: http://www.who.int/dg/speeches/2012/ tobacco_20120320/en.

56 L. Gruszczynski, 'Australian Plain Packaging Law, International Litigations and Regulatory Chilling Effect' (2014) 5(2) European Journal of Risk Regulation, pp. 242-7, at 244.

57 Ibid.; Bonnitcha, n. 26 above.

58 Case information is available at: http://www.international.gc.ca/trade-agreements-accords-commerciaux/ topics-domaines/disp-diff/agrosciences.aspx?lang=eng.

59 Available at: http://legisquebec.gouv.qc.ca/en/ShowDoc/cr/P-9.3,\%20r.\%201.

60 L. Peterson, 'Dow Suit is Seminal NAFTA Chapter 11 Test', Embassy Magazine, 15 Apr. 2009; H. Mann, 'DOWning NAFTA?', Investment Treaty News, 2 May 2009, available at: https://www.iisd. org/itn/2009/05/03/downing-nafta. 
led several observers to hypothesize that Dow initiated the dispute in the hope of having a chilling effect on other jurisdictions in Canada that were considering or developing similar bans. ${ }^{61}$ The case was ultimately settled and does not appear to have had a detrimental impact on the regulation of pesticides in Canada. Nevertheless, Dow clearly thought that it was worth trying and, in a different context, it might have been a more viable strategy.

\section{FOSSIL FUELS AND TOBACCO: FIGHTING FOR SURVIVAL}

As noted above, a number of ISDS cases relate to climate change. There may be many other cases that have not (yet) come to light in which the threat of arbitration has been used to stall action on climate change. However, the focus of this section is not on what might have already occurred but instead on what is likely to occur in the future. It is argued here that the strong parallels between the tactics used by the tobacco industry and the fossil fuel industry in response to proposed regulation suggest that when countries begin to ramp up action on climate change, fossil fuel corporations will employ ISDS in the same way that Philip Morris has.

In recent years, a number of authors have charted the collaborations between the tobacco and fossil fuel industries ${ }^{62}$ and commented on the use by both industries of 'merchants of doubt': scientists or faux experts willing to argue against scientific consensus for a fee. ${ }^{63}$ The Center for International Environmental Law (CIEL) has documented how the 'tobacco playbook' was actually invented by the fossil fuel industry, and how the two industries have, over the years, shared advertising agencies and public relations firms, as well as 'experts'. ${ }^{64}$ In the context of this article, what is most important is that all of these efforts for the past 50 to 60 years have been focused primarily on delaying regulatory action.

A number of parallels can be drawn between the tobacco and fossil fuel industries that explain their focus on stalling policy development. They also show why ISDS is a viable tactic for achieving this in addition to the tried-and-true methods of misinformation and lobbying. The first parallel is that both industries face 'existential threats' and are 'fighting for survival'. ${ }^{65}$ This is not the case for all industries faced with increased regulation, which often only translates into increased costs and possibly lower profit margins. Tobacco cannot be made healthy, nor can burning fossil fuels be made environmentally friendly (unless one believes the fantasy of 'clean coal'). If a government or the public decides that putting an end to lung cancer or climate change is a priority, then this means that the tobacco or fossil fuel

61 Mann, ibid.; K. Cooper et al., 'Seeking a Regulatory Chill in Canada: The Dow Agrosciences NAFTA Chapter 11 Challenge to the Quebec Pesticides Management Code' (2014) 7(1) Golden Gate University Environmental Law Journal, pp. 5-52.

62 See, e.g., J. Nesbit, Poison Tea: How Big Oil and Big Tobacco Invented the Tea Party and Captured the GOP (Thomas Dunne, 2016).

63 N. Oreskes \& E. Conway, Merchants of Doubt (Bloomsbury Press, 2010).

64 CIEL, 'Smoke and Fumes', available at: https://www.smokeandfumes.org.

65 R. Reavy, 'Survival is Victory: Lessons from the Tobacco Wars', Presentation to the $111^{\text {th }}$ RMCMI Convention and Annual Meeting, Snowmass, CO (US), 28-30 Jun. 2015, available at: http://www.eenews.net/ assets/2016/08/25/document_cw_01.pdf. 
industries must be regulated out of existence. While corporations in such a situation may consider selling different products, they are likely to fight tooth-and-nail to market their existing products for as long as possible because of their substantial sunk investments in the sector (such as infrastructure and control of commodity chains). Corporations in both the tobacco and fossil fuel industries have experimented with alternative products (e-cigarettes and renewable energy, respectively), but neither has been willing to give up on the more profitable and well-established products. The continued desire of corporations in these industries to hold on for as long as possible means that they will use every strategy at their disposal, including ISDS. This is true even if they know that they are highly unlikely to win a case, because the years during which proceedings are ongoing may deliver them considerable profits in other jurisdictions.

The second parallel is that neither industry has a particularly good reputation with the public. Appearing 'nice' is largely irrelevant to their brand value. For some corporations, bringing a massive claim for compensation against a sovereign state might have a negative impact in terms of public relations. For example, Bechtel dropped its ISDS case against Bolivia following a concerted international civil society campaign, presumably because the harm being done to the firm's reputation outweighed the potential benefits of winning the case. ${ }^{66}$ There is no indication that suing Australia and Uruguay has had any impact on Philip Morris cigarette sales.

Thirdly, both industries are being targeted for regulation at the international level. In the case of tobacco, there is the Framework Convention on Tobacco Control ${ }^{67}$ and, in the case of fossil fuels, there are the UNFCCC and its Paris Agreement, as well as other initiatives such as the G20 pledges to reduce fossil fuel subsidies. ${ }^{68}$ While framework agreements are largely voluntary and do not specify the particular actions that countries should take, they certainly play a role in pressuring states to act and also amplify the potential for a policy developed in one state to be mimicked in others. This is what happened with plain packaging legislation: first introduced in Australia, it has had a domino effect around the world. However, Philip Morris successfully delayed the falling of some of the dominoes by using ISDS. Fossil fuel corporations will hope to do the same when governments begin to adopt stricter climate policies.

Finally, both industries are dominated by a small group of extremely wealthy and truly multinational corporations. This means that they have the means and opportunities to engage in ISDS practically anywhere in the world. If one corporation does not have direct access to a treaty, the investment can be restructured through a subsidiary in a country where a treaty relationship exists. Philip Morris lost its case against Australia because it restructured its investment through Hong Kong, but other tribunals have been willing to accept jurisdiction when investors have engaged in

66 Democracy Center, 'Bechtel vs Bolivia: Details of the Case and the Campaign', available at: http://democracyctr.org/bolivia/investigations/bolivia-investigations-the-water-revolt/bechtel-vs-boliviadetails-of-the-case-and-the-campaign.

67 Geneva (Switzerland), 21 May 2003, available at: http://apps.who.int/iris/bitstream/10665/42811/1/ 9241591013.pdf?ua=1.

68 G20 Leaders Statement, Pittsburgh Summit, Pittsburgh, PA (US), 24-25 Sept. 2009, para 24, available at: http://www.g20.utoronto.ca/2009/2009communique0925.html. 
'treaty shopping' ${ }^{69}$ Tobacco and fossil fuel corporations can also collaborate across their respective industries to bring cases in different parts of the world or to pile on in one jurisdiction to have maximum impact. The costs of ISDS, while high for many governments, are insignificant for corporations of this size.

Both industries are clearly aware of the power of ISDS and have therefore lobbied for its inclusion in agreements like the TPP. Philip Morris made a public submission to the US Trade Representative on the TPP, describing ISDS as 'vital', and effectively mapping the countries that the company wanted to sue. ${ }^{70}$ Similarly, in a submission to the US Trade Representative in 2013, Chevron argued that the existence of ISDS panels increases the likelihood' of disputes being settled outside them. ${ }^{71}$ Furthermore, the minutes of a meeting in April 2014 between unnamed Chevron executives and European Commission officials (obtained by The Guardian under access to information laws) note that Chevron believes that 'the mere existence of ISDS is important as it acts as a deterrent'. ${ }^{72}$ However, while tobacco and fossil fuel corporations both recognize the power of ISDS, the fossil fuel industry has far more experience with the process in practice than the tobacco industry does. Fossil fuel corporations have been launching contractual and treaty-based investment disputes over direct expropriations and other issues, such as tax increases, for decades. Thus, they are already comfortable with ISDS and understand how and when to use it. Applying this tactic to the new area of climate change policy will be fairly straightforward.

In summary, fossil fuel corporations are faced with an existential threat to their business model; they have the resources to engage in ISDS and no good reason not to. Critically, they do not need to believe that they will win the cases that they launch, simply that dragging a policy through ISDS in one jurisdiction might delay its adoption in another. In light of this, one could reasonably question why there have not to date been any ISDS cases directly focused on climate policy. The obvious answer is that, thus far, the other tactics employed by fossil fuel corporations (such as lobbying and misinformation campaigns) have been very successful in preventing the adoption of any policies that would be worth challenging in ISDS.

\section{RESPONDING TO REGULATORY CHILL: SAFEGUARDS AND THE TPP CARVE-OUT}

In order to respond to concerns both about the impact that ISDS cases have on the public purse and the potential for regulatory chill, governments have made attempts to tighten up the language in regional trade agreements as well as in

69 J. Baumgartner, Treaty Shopping in International Investment Law (Oxford University Press, 2016).

70 'Submission of Philip Morris International in Response to the Request for Comments concerning the Proposed Trans-Pacific Partnership Trade Agreement', 25 Jan. 2010, (on file with the author).

71 E. Scott, Letter from Edward B. Scott, Vice President and General Counsel, Chevron Upstream Oil and Gas to Mr Douglas Bell, Chairman of the Trade Policy Staff Committee, Office of the US Trade Representative, 7 May 2013, available at: https://assets.documentcloud.org/documents/1237936/ttiplobbybrief-chevron.pdf.

72 A. Nelsen, 'TTIP: Chevron Lobbied for Controversial Legal Right as "Environmental Deterrent"', The Guardian, 26 Apr. 2016, available at: https://www.theguardian.com/environment/2016/apr/26/ ttip-chevron-lobbied-for-controversial-legal-right-as-environmental-deterrent. 
new BITs. The aim has been to restrict the scope for creative interpretation of provisions by arbitrators, but experts are divided about whether any of the 'safeguards' that have been introduced will prove effective in protecting public policies from challenge. ${ }^{73}$ In some cases, it is clear that the provisions that are lauded by governments are merely window dressing. For example, Article 9.16 of the TPP states:

Nothing in this Chapter shall be construed to prevent a Party from adopting, maintaining or enforcing any measure otherwise consistent with this Chapter that it considers appropriate to ensure that investment activity in its territory is undertaken in a manner sensitive to environmental, health or other regulatory objectives. ${ }^{74}$

This provision provides no real protection for public policies because the term 'otherwise consistent' renders it tautological. However, it is worth addressing in greater detail some of the other, more significant, safeguards. This section will focus primarily on those included in the TPP, as this is the most significant recent trade agreement to complete the negotiation stage. Although the TPP is now effectively defunct - at least in any form that will include the US - it is considered by many actors (such as the governing Liberal/National Coalition in Australia and the former National Party-led government in New Zealand) to be the 'gold standard' of trade agreements and it is likely that its provisions will crop up elsewhere, particularly in the RCEP, which has a significant degree of overlap in membership.

\subsection{National Treatment and Most Favoured Nation Treatment}

One would think that the clauses in investment treaties that prevent governments from discriminating between investors on the basis of nationality would be fairly uncontroversial. Unfortunately, arbitral tribunals have read 'national treatment' and 'most favoured nation (MFN) treatment' clauses broadly as covering not only de jure discrimination but also de facto discrimination. In other words, there does not have to be evidence of intent to discriminate on the part of the state.

Some treaties, including the TPP, restrict the definitions of national treatment and MFN treatment by including the qualifier that these provisions apply only to investors in 'like circumstances'. In theory, this approach offers a narrower scope for comparison than treaties with no qualifying language, but in practice a large ambit for interpretation remains. Tribunals are free to determine the criteria on which to assess which investors/investments are in like circumstances; there is no requirement that a tribunal must consider issues such as the environmental impact of an

73 Allen and Overy LLP, 'New Investment Protections Offered in Ground-Breaking Trans-Pacific Partnership', 23 Dec. 2016, available at: http://www.allenovery.com/publications/en-gb/Pages/Newinvestment-protections-offered-in-ground-breaking-Trans-Pacific-Partnership.aspx; L. Johnson \& L. Sachs, 'The TPP's Investment Chapter: Entrenching, Rather than Reforming, a Flawed System', Columbia Center on Sustainable Investment (CCSI) Policy Paper, Nov. 2015, available at: http:/ccsi.columbia.edu/files/2015/11/TPP-entrenching-flaws-21-Nov-FINAL.pdf; K. Tienhaara \& T. Tucker, 'Regulating Foreign Investment: Methanex Revisited', in C.L. Lim (ed.), Alternative Visions in the International Law on Foreign Investment: Essays in Honour of M. Sornarajah (Cambridge University Press, 2016), pp. 255-88.

74 Emphasis added. 
investment activity, which from a state's perspective could provide a justifiable reason for differentiation. ${ }^{75}$ If a tribunal is willing to consider the regulatory context (for instance, taking into account environmental and health policy objectives), it is likely to place the burden on the state to show that the discrimination was 'reasonable'. ${ }^{76}$ Furthermore, even where policy objectives are deemed to be reasonable, a tribunal may still find that the regulatory measures themselves are not if the same objectives could have been achieved in a less restrictive way. ${ }^{77}$

Miles suggests that states that differentiate between investments on the basis of sustainability goals are at risk of facing investor claims for breach of the national treatment standard. ${ }^{78}$ In the decision in Bilcon v. Canada the tribunal determined that the decision of an independent environmental review panel constituted a breach of the national treatment standard because a higher standard of environmental review was applied than was the case for other investments in like circumstances. ${ }^{79}$ Canada's arguments that the other projects reviewed were different in scope, in different locations, and involved different concerns (and therefore were not in like circumstances) were rejected by the tribunal. ${ }^{80}$

The TPP contains a footnote that is intended to deal with this issue:

For greater certainty, whether treatment is accorded in 'like circumstances' under Article 9.4 (National Treatment) or Article 9.5 (Most-Favoured-Nation Treatment) depends on the totality of the circumstances, including whether the relevant treatment distinguishes between investors or investments on the basis of legitimate public welfare objectives. ${ }^{81}$

However, this language will not be effective in preventing cases like Bilcon from arising under the TPP, because investors have proved their willingness to question before tribunals the legitimacy of government actions taken in the public interest. As Johnson and Sachs point out, a far more effective safeguard would have been to 'clearly specify that a foreign investor seeking to recover on a non-discrimination claim must establish that the government discriminated against it on account of its nationality'. ${ }^{82}$

An additional problem with the MFN provision in the TPP is its potential use by investors to access provisions in other investment treaties. In Maffezini v. Spain the tribunal decided that the MFN clause in the Spain-Argentina BIT could be applied to allow the claimant to have access to dispute resolution provisions in a BIT between

75 K. Miles, 'Sustainable Development, National Treatment and Like Circumstances in Investment Law', in M. Cordonier Segger, M. Gehring \& A. Newcombe (eds), Sustainable Development in World Investment Law (Kluwer Law International, 2011), pp. 261-94.

76 M. Wilensky, 'Reconciling International Investment Law and Climate Change Policy: Potential Liability for Climate Measures under the Trans-Pacific Partnership' (2015) 45 Environmental Law Reporter, pp. 10683-98.

77 Miles, n. 75 above.

78 Ibid.

79 Bilcon of Delaware et al. v. Government of Canada, Award on Jurisdiction and Liability, 17 Mar. 2015, available at: http://www.pcacases.com/web/view/50.

80 Johnson \& Sachs, n. 73 above.

81 TPP, n. 5 above, Ch. 9 , n. 14.

82 Johnson \& Sachs, n. 73 above, p. 10. 
Spain and Chile. ${ }^{83}$ The Maffezini decision prompted states to explicitly carve out ISDS provisions from the application of the MFN clause in more recent treaties. The TPP follows this trend.

However, investors have also successfully imported the substantive provisions of other treaties through the application of MFN. ${ }^{84}$ The CETA attempts to deal with this issue, stating:

Substantive obligations in other international investment treaties and other trade agreements do not in themselves constitute 'treatment', and thus cannot give rise to a breach of this article, absent measures adopted by a Party pursuant to such obligations. ${ }^{85}$

The 2015 Indian Model BIT ${ }^{86}$ deals with the problem even more effectively by simply excluding any mention of MFN in the text (the country having been stung by the use of MFN to import substantive obligations from another treaty in a case brought by an Australian investor). ${ }^{87}$

The TPP does not contain an effective safeguard against the 'MFN loophole' and, as such, it is possible that investors will try to exploit it, thus rendering the other safeguards in the TPP irrelevant. George Kahale III, chairman of Curtis, MalletPrevost, Colt \& Mosle LLP (a leading arbitration firm), argues that including an MFN clause in the investment chapter of the TPP was a 'major mistake' and it is 'a dangerous provision to be avoided by treaty drafters whenever possible' because it can turn one bad treaty into protections 'never imagined for virtually an entire world of investors. 88

\subsection{The International Minimum Standard and Fair and Equitable Treatment}

The international minimum standard treatment (MST) and fair and equitable treatment (FET) (which could be two distinct standards or one and the same, depending on the treaty in question and the person interpreting it) are the most problematic standards in investment treaties from the perspective of the right to regulate.

The difficulty stems primarily from the fact that "the concepts "fair" and "equitable" are by themselves inherently subjective and therefore lacking in precision'. ${ }^{89}$ Under one interpretation of the standard, states are required to meet the 'legitimate expectations' of the investor.

83 Emilio Agustin Maffezini v. The Kingdom of Spain, ICSID Case No. ARB/97/7, Award, 13 Nov. 2000.

84 C. Salomon \& S. Friedrich, 'How Most Favoured Nation Clauses in Bilateral Investment Treaties Affect Arbitration' (2013) Practical Law Arbitration, available at: http://www.lw.com/thought Leadership/favoured-nation-clauses-arbitration.

85 CETA, n. 8 above, Art. 8.7(4).

86 'Model Text for the Indian Bilateral Investment Treaty', available at: https://www.mygov.in/sites/ default/files/master_image/Model\%20Text\%20for\%20the\%20Indian\%20Bilateral\%20Investment $\% 20$ Treaty.pdf.

87 P. Ranjan, 'The White Industries Arbitration: Implications for India's Investment Treaty Program', Investment Treaty News, 13 Apr. 2012, available at: https://www.iisd.org/itn/2012/04/13/the-whiteindustries-arbitration-implications-for-indias-investment-treaty-program.

88 J. Hill, 'TPP's Clauses that Let Australia Be Sued Are Weapons of Legal Destruction, Says Lawyer', The Guardian, 10 Nov. 2015, available at: https://www.theguardian.com/business/2015/nov/10/tppsclauses-that-let-australia-be-sued-are-weapons-of-legal-destruction-says-lawyer.

89 UNCTAD, Fair and Equitable Treatment, UNCTAD/ITE/IIT/11(Vol.III) (United Nations, 1999). 
The most common safeguard is to clarify, as the TPP does, that FET does not require treatment in addition to or beyond that which is required under customary international law. Unfortunately, this safeguard has proved to be ineffective in practice because some arbitrators view the decisions of past tribunals (who have interpreted the standard broadly) as now forming part of customary international law. The same safeguard was introduced in the NAFTA ${ }^{90}$ in 2001 through a joint note of interpretation by the parties. ${ }^{91}$ This did not prevent the majority of the NAFTA tribunal in Bilcon v. Canada from determining that an alleged violation of Canadian domestic law amounted to a breach of customary international law. The US and Mexico have criticized the Bilcon award in submissions filed in another arbitration for failing 'to properly assess customary international law'. ${ }^{92}$

A further safeguard in the TPP's investment chapter is the qualifier to MST/FET that ' $[t]$ he mere fact that an action is taken that is inconsistent with an investor's expectations does not constitute a breach ... even if there is loss or damage to their investment as a result of that action'. ${ }^{93}$ Unfortunately, this language not only fails to act as a safeguard but could actually expose governments to greater risk. Firstly, no finding of an MST/FET violation has ever rested solely on the fact that an investor's expectations were not met. Todd Weiler, a Canadian lawyer/arbitrator and proponent of ISDS, has noted that he 'can't recall any tribunal that, if you put this provision in that agreement, the result would be different either way'. ${ }^{94}$

Secondly, in the past, governments (including the US) have clearly asserted that an investor's 'expectations' are not to be considered at all in the determination of a breach of MST/FET. The TPP, by stating that a breach of an investor's expectations does not alone give rise to a claim, "implicitly recognizes that "expectations" may in fact be relevant to establishing a violation of the FET standard'. ${ }^{95}$ Thus, the TPP 'codifies - rather than corrects - problematic decisions such as the Bilcon award'.96

The preferable option to safeguard against expansive interpretations of the MST would be to exclude any mention of 'fair and equitable treatment'. This is the approach taken by India in its 2015 Model BIT.

\subsection{Indirect Expropriation}

Historically, the direct taking of foreign property has been one of the most significant risks to foreign investment. Instances of outright taking are now considered rare in most parts of the world. For the last 20 years, the key debate in academic and

90 N. 4 above.

91 NAFTA Free Trade Commission, 'Notes of Interpretation of Certain Chapter 11 Provisions', 31 July 2001, available at: http://www.sice.oas.org/tpd/nafta/Commission/CH11understanding_e.asp.

92 Government of Canada, 'Bilcon v Canada Case Summary', available at: http://www.international.gc.ca/ trade-agreements-accords-commerciaux/topics-domaines/disp-diff/clayton.aspx?lang=eng.

93 TPP, n. 5 above, Art. 9.6(4).

94 Quoted in 'TPP Investment Language Aims to Tighten Standard for MST Breach', Inside U.S. TradeWorld Trade Online, 12 Nov. 2015, available at: http://insidetrade.com/inside-us-trade/tppinvestment-language-aims-tighten-standard-mst-breach.

95 Johnson \& Sachs, n. 73 above, p. 4.

96 Ibid. 
policy circles has been on the coverage in investment treaties of so-called indirect expropriation. Indirect expropriation falls short of actual physical taking of property but results in the effective loss of management, use or control, or a significant depreciation in the value of the assets of a foreign investor. ${ }^{97}$

In establishing whether or not an indirect expropriation has occurred, tribunals have tended to adopt one of two basic approaches. Under the first approach, the tribunal focuses solely on the effect of the regulation on the investor. ${ }^{98}$ To evaluate the effect of a measure, tribunals are likely to examine both its economic impact and its duration. Tribunals which adopt the second approach will also examine the effect of a measure on an investor, but will additionally address its purpose. The tribunal will assess whether a measure was taken for a legitimate public purpose and may also evaluate whether the need to fulfil that purpose is proportionate to the negative effect felt by the investor. Given the difficulty of drawing a bright line between bona fide non-compensable regulation and a taking, many commentators and arbitrators suggest that such a determination can be achieved only on a case-by-case basis. ${ }^{99}$

Safeguards to prevent tribunals from adopting overly broad, investor-friendly interpretations of indirect expropriation that might interfere with the right to regulate have typically followed the US model, which is based on domestic case law on regulatory takings. ${ }^{100}$ This model relies on an annex with two distinct elements. The first element is a three-part test which addresses the effect of a measure, its character, and the extent to which it interferes with the investor's 'reasonable' or 'legitimate' expectations. The second element is a statement that 'except in rare circumstances' non-discriminatory regulatory measures are not considered to be expropriations.

In some treaties, a provision (usually stated before the three-part test) is included which stipulates the level of deprivation that must have occurred for a measure to be considered a possible expropriation. For example, the Taiwan-New Zealand BIT (2013) states that '[i]n order to constitute indirect expropriation, the Party's deprivation of the investor's property must be: (a) either severe or for an indefinite period'. ${ }^{101}$ The Canada-Korea Free Trade Agreement (2014) states: 'An action or series of actions by a Party cannot constitute an expropriation unless it interferes with a tangible or intangible property right in an investment and eliminates all or nearly all of its value. ${ }^{102}$

In the treaty practice of countries such as Canada and Colombia, an additional note is included in the expropriation annex clarifying what 'rare circumstances' might

\footnotetext{
97 UNCTAD, ‘Taking of Property', UNCTAD/ITE/IIT/15 (United Nations, 2000).

98 Y. Fortier \& S. Drymer, 'Indirect Expropriation in the Law of International Investment: I Know It When I See It, or Caveat Investor' (2004) 19(2) ICSID Review: Foreign Investment Law Journal, pp. 293-327, at 300.

99 Ibid.

100 Tienhaara \& Tucker, n. 73 above.

101 Agreement between New Zealand and the Separate Customs Territory of Taiwan, Penghu, Kinmen, and Matsu on Economic Cooperation, 10 July 2013, in force 1 Dec. 2013, Annex 5, para 3, available at: https://www.nzcio.com/assets/ANZTEC/ANZTEC-Expropriation-Annex-5-10-July-2013-NZ.pdf.

102 Seoul (South Korea), 11 Mar. 2014, in force 1 Jan. 2015, Ch. 8, Annex 8-B, para. (b), available at: http://international.gc.ca/trade-commerce/trade-agreements-accords-commerciaux/agr-acc/korea-coree/ fta-ale/index.aspx?lang=eng (emphasis added).
} 
entail: 'such as when a measure or series of measures is so severe in the light of its purpose that it cannot be reasonably viewed as having been adopted and applied in good faith'. Some countries (Turkey, for example) opt to exclude the 'rare circumstances' language altogether. ${ }^{103}$

The TPP adopted the US model annex without any of these additional qualifications. The only amendment to the standard model is a footnote with the following explanation:

Whether an investor's investment-backed expectations are reasonable depends, to the extent relevant, on factors such as whether the government provided the investor with binding written assurances and the nature and extent of governmental regulation or the potential for government regulation in the relevant sector. ${ }^{104}$

In some other treaties, this issue is dealt with by using the language of 'specific commitments' rather than 'investment-backed expectations'. The term 'specific commitments' is narrower than 'investment-backed expectations', although some investment law experts maintain that neither belongs in the analysis of whether a regulatory measure is an expropriation. ${ }^{105}$

What the TPP safeguard achieves is a rejection of the sole-effects approach to determining whether an indirect expropriation has occurred. However, it leaves open the door to a proportionality analysis, which Sornarajah argues has been imported into investment law from the trade context to 'keep alive the idea that compensation is possible even in the case of regulatory expropriations'. ${ }^{106}$

It is unclear what impact Article 3b (the 'except in rare circumstances' clause) might have in protecting the right to regulate. As Edsall notes in relation to a similar clause in the Central American Free Trade Agreement (CAFTA): 107 'Given the vague nature of the term "rare circumstances", it could be a comparatively broad exception to the presumption in favor of "nondiscriminatory regulatory actions", 108 It is also unclear how this clause relates to those that precede it. In an intervention into a case brought under CAFTA against Costa Rica, the US government made it clear that it does not view the relationship between the clauses in the Annex on indirect expropriation as hierarchical, noting that the paragraph stating that regulatory measures are not expropriatory except in rare circumstances 'is not an exception, but rather is intended to provide tribunals with additional guidance in determining whether an indirect expropriation has occurred'. ${ }^{109}$ This case, which arose over

103 Tienhaara \& Tucker, n. 73 above.

104 TPP, n. 5 above, Annex 9-B, n. 36.

105 M. Sornarajah, Resistance and Change in the International Law on Foreign Investment (Cambridge University Press, 2015).

106 Ibid., p. 211.

107 Washington, DC (US), 28 May 2004, in force 1 Jan 2009, available at: https://ustr.gov/trade-agreements/free-trade-agreements/cafta-dr-dominican-republic-central-america-fta/final-text.

108 R. Edsall, 'Indirect Expropriation under NAFTA and DR-CAFTA: Potential Inconsistencies in the Treatment of State Public Welfare Regulations' (2006) 86 Boston University Law Review, pp. 931-62, at 958 .

109 US Government, US Article 10.20.2 Submission in Spence v. Costa Rica, ICSID Case No. UNCT/13/2, 17 Apr. 2015, available at: http://www.state.gov/documents/organization/242886.pdf (emphasis added). 
Costa Rica's move to establish a park to protect the nesting sites of endangered leatherback sea turtles, also demonstrates the willingness of investors to argue that their case is a 'rare circumstance'.

\subsection{The Tobacco Carve-Out}

What the above demonstrates is that, despite the introduction of a number of safeguards, substantial ambiguity exists in the text of the TPP. Ambiguity equals regulatory uncertainty and thus regulatory chill remains a concern. However, there is one safeguard included in the TPP that was widely expected to be effective in countering regulatory chill: the so-called tobacco carve-out. Article 29.5 of the TPP on Tobacco Control Measures allows governments to 'elect to deny the benefits of Section B of Chapter 9' (i.e. ISDS) 'with respect to claims challenging a tobacco control'. ${ }^{110}$ Unless a government wishes to leave itself open to litigation over a policy like requiring plain packaging of tobacco, it would not be, at least not under the TPP.

Although some questions have been raised about the wording of the carve-out (particularly the fact that invoking it is optional) and what it fails to cover (tobacco leaf and possibly e-cigarettes), its inclusion in the agreement is generally considered a substantial win for health advocates. ${ }^{111}$ However, somewhat ironically, the mere existence of the carve-out tends to create at least the perception that the other safeguards in the TPP's investment chapter are inadequate to shield health policies from investor challenges. ${ }^{112}$

A cynic might suggest that the carve-out was included simply to quell opposition to the TPP from civil society, particularly in Australia. However, a recent development casts some doubt on that theory. In October 2016, Australia and Singapore quietly adopted an amendment to their existing free trade agreement by inserting a tobacco carve-out. ${ }^{113}$ This move, made after the Philip Morris claims against Australia and Uruguay had been dismissed, and with no fanfare, suggests that one or both of these countries continues to view tobacco ISDS claims as a threat. The carve-out serves to rule out the possibility of an ISDS case (although only from corporations based or structured through Australia or Singapore) and thereby any cross-border chilling effect from cases brought in other jurisdictions.

While widely viewed as effective, ${ }^{114}$ there are critics of the tobacco carve-out at both ends of the political spectrum. Under the influence of the tobacco lobby,

110 TPP Chapter 29 is available at: http://dfat.gov.au/trade/agreements/tpp/official-documents/Documents/ 29-exceptions-and-general-provisions.pdf.

${ }^{111}$ K. Hirono, D. Gleeson \& V. Freeman, 'To What Extent Does a Tobacco Carve-Out Protect Public Health in the Trans-Pacific Partnership Agreement?' (2016) 26(2) Public Health Research Practice, pp. $1-3$, at 1 .

112 Johnson \& Sachs, n. 73 above; J. Surowiecki, 'The Corporate-Friendly World of the TPP', The New Yorker, 6 Oct. 2015, available at: http://www.newyorker.com/news/daily-comment/the-corporatefriendly-world-of-the-t-p-p.

113 Australia and Singapore, Agreement to Amend the Singapore-Australia Free Trade Agreement, 13 Oct. 2016, available at: http://ffat.gov.au/trade/agreements/safta/Documents/agreement-to-amend-thesingapore-australia-free-trade-agreement.pdf.

114 S. Puig \& G. Shaffer, 'A Breakthrough with the TPP: The Tobacco Carve-out' (2016) 16(2) Yale Journal of Health, Policy and Ethics, pp. 327-33; S. Sinclair, 'The TPP and Health Care', in S. Sinclair 
Republicans in the US Senate held up the ratification of the TPP in 2016, in part because they objected to the carve-out. ${ }^{115}$ They expressed concern about a 'slippery slope' where tobacco would just be the first in a long line of industries to be excluded from protection. This concern is shared by many ISDS proponents. For example, Mercurio argues: 'After tobacco, other disfavoured industries could subsequently be targeted - perhaps alcohol, sugar or even mining' ${ }^{116}$ At the other end of the spectrum, opponents of ISDS would welcome any or indeed all of these industries being excluded from the investment protection provisions in trade agreements. For these critics the problem with the TPP carve-out is not that it could set a dangerous precedent, but that it is too narrow in scope. They argue that tobacco control is not the only policy area worthy of special protection. ${ }^{117}$

This article sides with the latter group of critics, based on the evidence that far more ISDS cases have been brought in relation to environmental regulations than to tobacco control measures, and the concerns outlined earlier in this article about the specific threat posed by fossil fuel companies challenging measures taken to address climate change. A carve-out for climate change measures in the TPP would have been far more significant than the tobacco carve out. The European Parliament has, in effect, called for such a carve-out in the TTIP (an agreement with an uncertain future under the Trump administration). ${ }^{118}$ In the lead-up to the December 2015 Paris conference, the European Parliament adopted a resolution calling on the European Commission and European Union (EU) Member States to:

ensure that any measure adopted by a Party to the Paris Agreement relating to the objective of stabilising greenhouse gas concentrations in the atmosphere at a level that would prevent dangerous anthropogenic interference with the climate system, or relating to any of the principles or commitments contained in Articles 3 and 4 of the UNFCCC, will not be subject to any existing or future treaty of a Party to the extent that it allows for investor-state dispute settlement. ${ }^{119}$

\& S. Trew (eds), The Trans Pacific Partnership and Canada: A Citizen's Guide (James Lorimer \& Co. Ltd, 2016), pp. 46-65, at 55.

115 V. Needham, 'Tobacco "Carve-Out” Sparks Bid to Sink TPP', The Hill, 8 Oct. 2016, available at: http://thehill.com/policy/finance/256311-tobacco-carve-out-sparks-bid-to-sink-tpp; J. Diamond \& D. Bash, 'Trump Signs Order Withdrawing from TPP, Reinstate “Mexico City Policy” on Abortion', CNN, 23 Jan. 2017, available at: http://edition.cnn.com/2017/01/23/politics/trans-pacific-partnershiptrade-deal-withdrawal-trumps-first-executive-action-monday-sources-say.

116 B. Mercurio, 'Australia Needs Precision Tools in Drafting Trade Agreements, Not a Sledgehammer', The Conversation, 27 Jan. 2017, available at: https://theconversation.com/australia-needs-precisiontools-in-drafting-trade-agreements-not-a-sledgehammer-70417.

117 Hirono, Gleeson \& Freeman, n. 111 above; Sinclair, n. 118 above; CHOICE, 'Trans-Pacific Partnership Agreement: Submission to the Joint Standing Committee on Treaties', 11 Mar. 2016, available at: https://www.choice.com.au/ /media/305edb1ce4d34c9c9917acaee3fce2cf.ashx?la=en.

118 A. Hammond, 'The Pain Will be Shared if Donald Trump Torpedoes "Worst Ever" Trade Deal', The Telegraph, 15 Aug. 2017, available at: http://www.telegraph.co.uk/business/2017/08/15/pain-willshared-donald-trump-torpedoes-worst-ever-trade-deal.

119 European Parliament Resolution 2015/2112(INI, 14 Oct. 2015, 'Towards a New International Climate Agreement in Paris', available at: http://www.europarl.europa.eu/sides/getDoc.do?pubRef=-//EP// TEXT+TA+P8-TA-2015-0359+0+DOC+XML+V0//EN. See also The Council of Canadians, 'EU Parliament Adopts Robust Mechanism Needed for Paris Climate Talks. Are European National Leaders Ready to Act?, 16 Oct. 2015, available at: http://canadians.org/media/eu-parliament-adoptsrobust-mechanism-needed-paris-climate-talks-are-european-national-leaders. 
Finally, a preferable alternative to carving out either tobacco or climate change measures is to carve them both out, as well as all other measures adopted by governments in pursuit of their international obligations. The Framework Convention on Tobacco Control ${ }^{120}$ could be explicitly listed alongside the climate treaties as well as a myriad of other environmental, human rights and indigenous rights agreements, leaving the option for further agreements to be added to the list as they are signed.

\section{CONCLUSIONS}

Investment agreements have been designed primarily to protect the status quo. Conversely, compliance with the objectives of the Paris Agreement will require radical change: a future in which governments have met the collective goal of keeping below the $2^{\circ} \mathrm{C}$ guardrail is a future without fossil fuels. Civil society and governments at all levels will have to fight for this future, regardless of whether any of the recently negotiated regional trade agreements ever actually come into force. However, providing fossil fuel corporations with ISDS under these agreements is akin to handing your opponent extra weapons and ammunition before stepping onto the battlefield. Fossil fuel corporations will always have sufficient incentive to bring ISDS cases because they are fighting for their survival. For as long as there is any ambiguity in the substantive provisions of investment agreements - allowing cases to play out over several years, cost millions, and leave governments uncertain about outcomes there will be policy delays. In a rapidly warming world, we simply cannot afford these delays.

The only provision that has been introduced into recent negotiations that would be remotely effective at protecting public policy from investor challenges is the tobacco carve-out found first in the (now defunct) TPP and more recently inserted into the Australia-Singapore Free Trade Agreement. ${ }^{121}$ However, in the future, negotiators should not confine themselves to carving out tobacco control measures. Instead, it is logical to carve out all government measures taken in furtherance of obligations under international agreements. Of course, an even simpler option is to leave investment protection out of regional trade agreements altogether (and cease to sign BITs), given the complete absence of any evidence that providing foreign investors with greater legal rights than those of domestic investors has any public benefit. 